\title{
ANALISIS KINERJ A ALAT DESALINASI AIR LAUT PENGHASIL AIR TAWAR DAN GARAM DENGAN MENGGUNAKAN TENAGA SURYA
}

\author{
Sopiyan Iqbal', Sukmawaty', Guyup Mahardhian Dwi Putra2*, Diah Ajeng Setiawati1 \\ ${ }^{1}$ Program Studi Teknik Pertanian, Fakultas Teknologi Pangan dan Agroindustri, Universitas Mataram \\ ${ }^{2}$ Program Studi Teknik Pertanian,Fakultas Teknologi Pangan dan Agroindustri, Universitas Mataram, guyupmdp@unram.ac.id
}

\section{INFO ARTIKEL}

RiwayatArtikel:

Diterima: 12-09-2018

Disetujui : 02-01-2019

\section{Kata Kunci:}

Air laut

Desalinasi

Energi surya

Volume destilat

\section{A. LATAR BELAKANG}

Indonesia secara geografis merupakan sebuah negara kepulauan dengan dua pertiga luas lautan yaitu, sekitar $3.288 .683 \mathrm{~km}^{2}$. Hal ini bisa terlihat dengan adanya garis pantai di hampir setiap pulau di Indonesia $( \pm 81.000 \mathrm{~km})$ yang menjadikan Indonesia menempati urutan kedua setelah Kanada sebagai negara yang memiliki garis pantai terpanjang di dunia. Melihat Indonesia yang terletak di tengah kepungan air laut, kekurangan air bersih banyak menimpa masyarakat yang tinggal di pesisir pantai.

Air merupakan salah satu kebutuhan pokok manusia untuk hidup. Penyediaan air bersih bagi seluruh lapisan masyarakat masih merupakan satu masalah besar di Indonesia. Untuk mengatasi hal tersebut perlu dilakukan upaya untuk mendapatkan air jernih dengan proses destilasi air laut.

Kepulauan Indonesia yang berada di sekitar garis katulistiwa memiliki iklim tropis sehingga mendapatkan penyinaran matahari sepanjang tahun. Energimatahari yang tersediamerupakansumberenergi yang murahdandapatdimanfaatkansebagaisumberenergialter natif [1]

Untuk dapat memanfaatkan energi surya tersebut khususnyadalam proses destilasi air laut, digunakan suatu perangkat untuk mengumpulkan energi radiasi matahari yang sampai ke permukaan bumi dan mengubahnya menjadi energi kalor yang berguna. Perangkat ini disebut dengan kolektor surya. Penelitian tentang kolektor surya bukanlah ide baru dalam dunia teknologi rekayasa surya. Telahbanyak para peneliti yang telahmenelitihalinisebelumnya, salahsatunyapenelitianterkaitdestilasi plat dataroleh[2] dimanaefisiensidestilasimencapai $8,48 \%$ dan rata-rata produktivitas air tawarmencapai $665 \mathrm{ml}$.

Nilai efisiensi destilat yang dicapai pada penelitian sebelumnya [2] dirasa masih sangat rendah. Oleh karena itu, penelitian inidiperlukan untuk mengetahui kinerja alat destilasi air laut berbasis energi surya, mengetahui produktivitas air tawar yang dihasilkan, serta menentukan kesetimbangan massa air laut yang diperlukan untuk mendapatkan efisiensi yang maksimal.

\section{B. METODE PENELITIAN}

\section{Waktu dan Tempat Pelaksanaan Penelitian}

Penelitian ini dilaksanakan pada 16-21 Juli 2018 di Fakultas Teknologi Pangan dan Agoindustri, Universitas Mataram.

\section{Alat dan Bahan}

Alat-alat yang digunakan pada penelitian ini adalah: 
a. Satu set alat destilator

Dimensi alat destilasi terdiri dari: evaporator dengan panjang $87 \mathrm{~cm}$ dan lebar $82 \mathrm{~cm}$, panjang sisi miring $92 \mathrm{~cm}$, tinggi bagian belakang $60 \mathrm{~cm}$ dan tinggi bagian depan 30 $\mathrm{cm}$ dengan tinggi kaki destilator $5 \mathrm{~cm}$ (Gambar 1).

b. Bakpenampung air (liter)

c. Gelas piala (ml)

d. Termokopel

Termokopel berfungsi untuk mengukur intesitas radiasi matahari $(\mathrm{W} / \mathrm{m} 2)$.

e. Termometer Digital

Termometer digital berfungsi untuk mengukur temperature (oC).

f. Termometer Air Raksa

Termometer Alkohol berfungsi untuk mengukur temperatur lingkungan (oC).

g. Stopwatch

Stopwatch digunakan untuk menentukan waktu pengambilan data (detik).

h. $\mathrm{pH}$ meter

Alat ini digunakan untuk mengukur $\mathrm{pH}$ air laut dan air tawar

i. TDS meter

Alat ini digunakan untuk mengukur kepekatan larutan air laut (ppm).

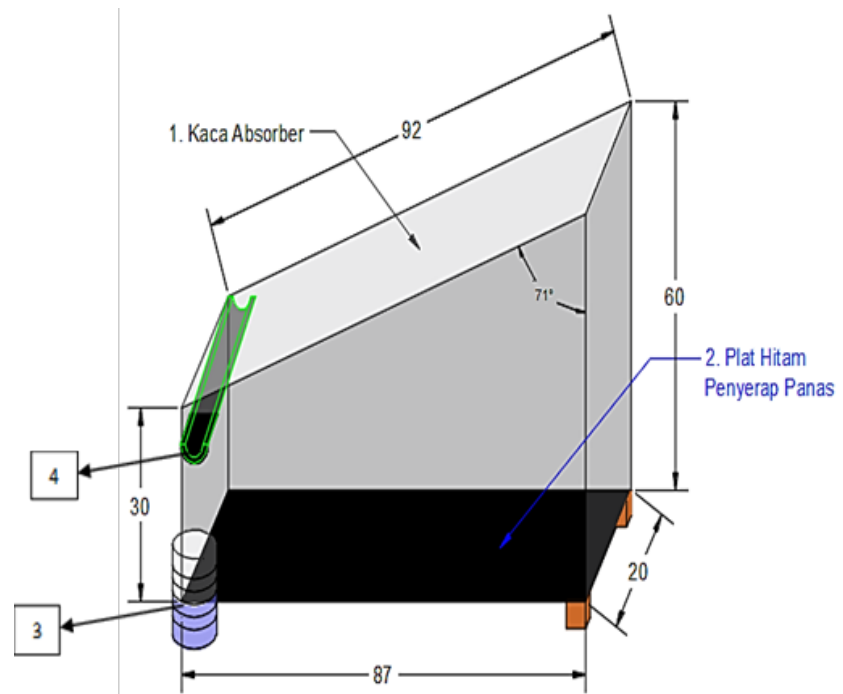

Keterangan:(1) kaca absorber, (2) plat hitam penyerap panas, (3) wadah penampung air tawar, (4) tube saluran destilat

Gambar 1. Destilator tenaga surya

Bahan yang digunakan dalam penelitian ini diambil Air laut 5 liter dari pantai Mapak Mataram.

\section{Metode dan Parameter Penelitian}

a. Metode penelitian

Metode yang digunakan dalam penelitian ini adalah metode eksperimentaldengan melakukan uji kinerja alat destilator dalam mendestilasikanair lautsebanyak 5 liter selama 5 hari (1 liter perhari secara kontinyu). pencatatan suhu setiap 1 jam mulai dari pukul
08.00-17.00 WITA dengan pemanasan tenaga surya.

b. Parameter yang diamati

Parameter yang diamati pada penelitian ini meliputi:

1. Suhu bak evaporator

Untuk mengambil data suhu bak evaporator, diletakkan sensor suhu termokopel untuk mencatat suhu dinding kaca, suhu penguapan dan suhu air laut.

2. Suhu lingkungan

Untuk mengambil data suhu lingkungan diletakkan termometer disekitar lingkungan pengamatan.

3. Kualitas fisik air hasil destilasi $(\mathrm{pH}, \mathrm{Suhu}$ air dan kadar garam)

Untuk mengambil data uji kualitas fisik air maka dilakukan pengujian sampel air tawar pada setiap selesai melakukan pengamatan perhari.

4. Volume garam dihasilkan

Untuk mengambil data Volume Garam digunakan timbangan analitik untuk mengetahui berat massa yang dihasilkan pada proses destilasi.

5. Kapasitas air Laut

Untuk mengambil data kapasitas air air laut maka digunakan perhitungan kapasitas volume maksimal pada evaporator.

c. Parameter yang dihitung

1. Kesetimbangan massa[3]

$\left.\Sigma_{\mathrm{t}}(\rho . \mathrm{A} . \mathrm{V})_{\text {masuk }}=\Sigma_{\mathrm{t}}(\rho . \mathrm{A} . \mathrm{V})_{\text {keluar }}+\mathrm{V}_{\text {garam }} 1\right)$

Keterangan:

$\rho=$ Massa Jenis Air Laut $\left(\mathrm{Kg} / \mathrm{m}^{3}\right)$

$\mathrm{A}=$ Luas Permukaa Air Laut $\left(\mathrm{m}^{2}\right)$

$\mathrm{V}=$ Volume air Laut (liter)

2. Energi radiasi yang diserap oleh plat penyerap[3]

Qin $=\alpha \times$ ITtot $x \operatorname{Ac}(4)$

Keterangan:

IT = intensitas surya $\left(\mathrm{W} / \mathrm{m}^{2}\right)$

$\mathrm{Ac}=$ Luas plat penyerap $\left(\mathrm{m}^{2}\right)$

$\alpha=$ absorpsivitas plat penyerap $(0,50)$

Qin= Energi radiasi yang sampai ke plat penyerap (Watt)

3. Energi yang berguna pada destilasi air laut[3]

$\mathrm{Qu}=\mathrm{m} \cdot \mathrm{Cp} \cdot \Delta \mathrm{T}+\mathrm{m} \times \mathrm{hfg}(3)$

Keterangan:

$\mathrm{Qu}=$ Energi yang berguna bagi kolektor (Watt)

$\mathrm{m}=$ Massa zat yang diuapkan (liter)

$\mathrm{Cp}=$ Panas spesifik zat $\left(\mathrm{J} / \mathrm{kg} \cdot \mathrm{m}^{2} .^{\circ} \mathrm{C}\right)$

$\Delta \mathrm{T}=$ Perbedaan temperatur $\left({ }^{\circ} \mathrm{C}\right)$

$\mathrm{Hfg}=$ Panas Laten Penguapan $\left(22,6 \times 10^{5}\right.$ $\mathrm{J} / \mathrm{kg}^{\circ} \mathrm{C}$ )

4. Energi yang hilang dari kolektor(Mulyanef, 2014)

Qloss $=$ a.ITtot. Ac $-\mathrm{m} \cdot \mathrm{Cp} \cdot \Delta \mathrm{T}+\mathrm{m} \times \mathrm{hfg}(4)$

Keterangan:

IT = intensitas surya $\left(\mathrm{W} / \mathrm{m}^{2}\right)$ 
$\alpha=$ absorpsivitas plat penyerap $(0,50)$

$\mathrm{Cp}=$ Panas spesifik zat $\left(\mathrm{J} / \mathrm{kg} . \mathrm{m}^{2} .^{\circ} \mathrm{C}\right)$

$\Delta \mathrm{T}=$ Perbedaan temperatur $\left({ }^{\circ} \mathrm{C}\right)$

$\mathrm{m}=$ Massa Zat yang diuapkan (liter)

hfg = Panas Laten Penguapan $\left(22,6 \times 10^{5}\right.$

$\left.\mathrm{J} / \mathrm{kg}^{\circ} \mathrm{C}\right)$

$\mathrm{Tp}=$ Temperatur plat penyerap $\left({ }^{\circ} \mathrm{C}\right)$

$\mathrm{Ta}=$ Temperatur lingkugan $\left({ }^{\circ} \mathrm{C}\right)$

$\mathrm{Ac}=$ Luas plat penyerap $\left(\mathrm{m}^{2}\right)$

5. Efisiensi alat destilasi air laut tenaga surya[3]

$\eta \mathrm{c}=\frac{\mathrm{Qu}}{\mathrm{Qin}} \times 100 \%$

Keterangan:

Qin= Energi radiasi yang sampai ke plat penyerap (Watt)

$\mathrm{Qu}=$ Energi yang berguna dari kolektor (Watt)

\section{Prosedur Penelitian}

Prosedur penelitian ini dapat dilihat pada Gambar 2 berikut.
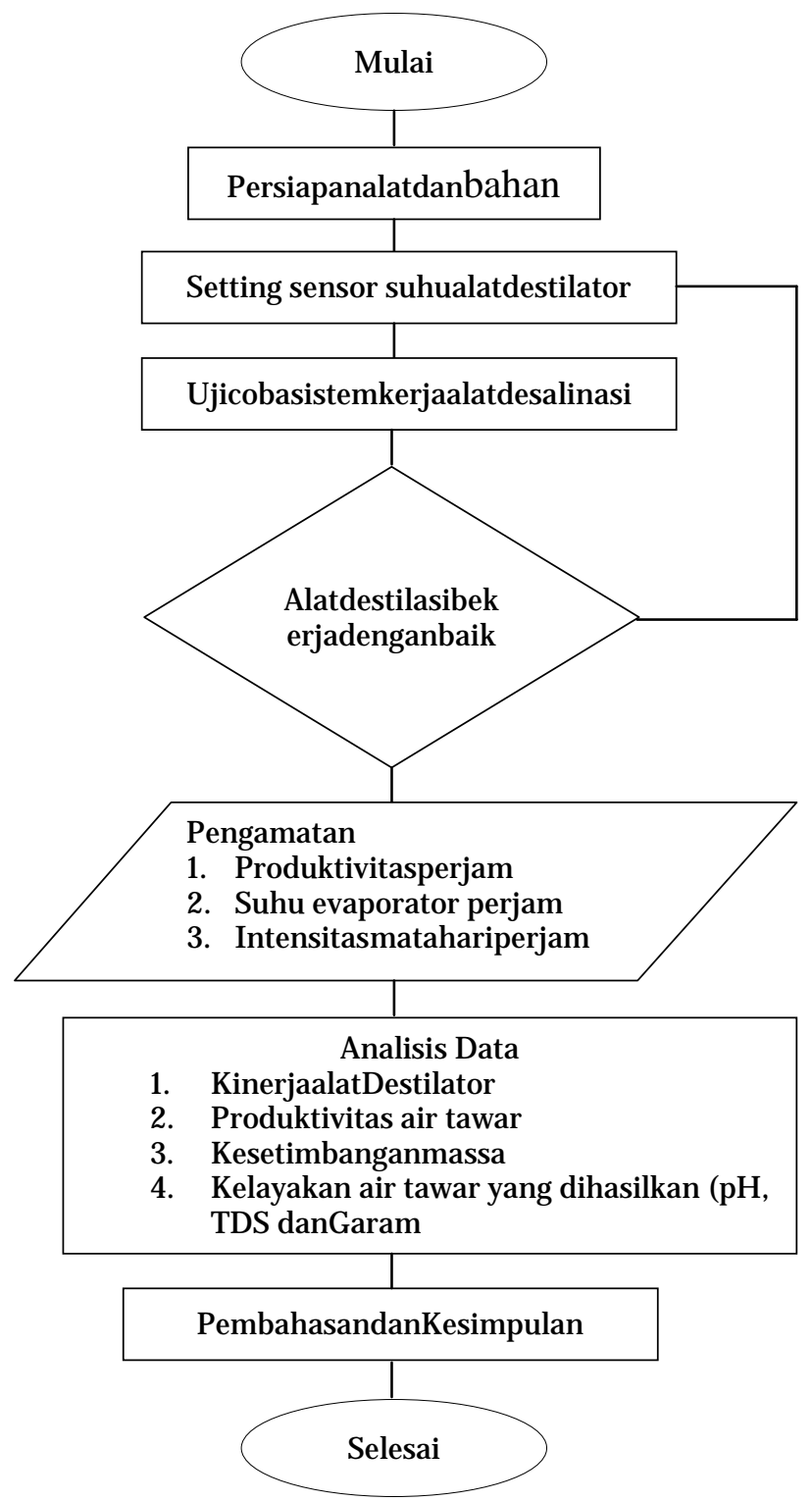

Gambar 2. Diagram alir penelitian

\section{HASIL DAN PEMBAHASAN}

\section{Kinerja Alat}

a. Intensitas Matahari

Data intensitas matahari selama 5 (lima) hari penelitian dapat dilihat pada Gambar 3 . Pada grafik tersebut terlihat bahwa intensitas matahari mengalami fluktuasi setiap harinya. Intensitas matahari secara umum meningkat pada pagi hari menuju siang hari dan menurun setelah siang hari menuju sore hari. Hal ini disebabkan karena gerak semu harian matahari (dari timur ke barat) menyebabkan perubahan sudutdatang sinar matahari yang mempengaruhi jumlah energi radiasi yang diterima oleh permukaan bumi. Semakin tegak posisi matahari dengan bumi, semakin besar energi yang diterima, sehingga umumnya intensitas sinar matahari yang terukur pada siang hari adalah paling tinggi dibandingkan waktu-waktu lainnya.

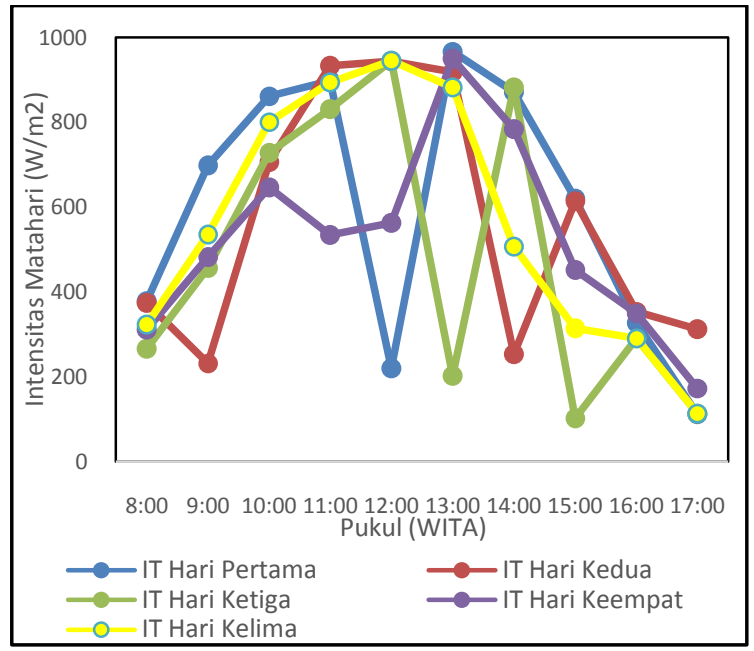

Gambar 3.Intensitassinarmatahariselama 5 haripengamatan

Padagambar 3 terlihat bahwa nilai intensitas sinar matahari pada hari pertama saat tengah hari (pukul 12.00) adalah yang terendah kedua pada hari tersebut. Sementara pada hari ketiga terjadi penurunan drastis intensitas matahari pada jam 13.00. Penurunan nilai intensitas matahari ini dapat disebabkan karena adanya penghalang berupa awan yang menaungi lokasi pengamatan pada waktu pengambilan data. Hal inisejalandengan[4] yang

menyatakanbahwanaikturunnyaintensitaspenyi naranmataharisangatdipengaruhiolehkeadaana wan di atmosfer.

Tabel 1 memperlihatkan intensitas matahari total setiap harinya selama pengamatan. Intensitas matahari sangat mempengaruhi suhu plat dan suhu penguapan yang terlihat meningkat seiring meningkatnya intensitas matahari. Adapun suhu lingkungan, air laut dan air tawar hasil destilasi menunjukkan nilai dengan pola yang berbeda dengan nilai intensitas matahari. 
AGROTEK Jurnae Vol. 6 No. 12019 / Analisis Kinerja Alat Desalinasi Air Laut Penghasil Air Tawar dan Garam dengan Menggunakan Tenaga Surya/ Sopiyan Iqbal, Sukmawaty, Guyup Mahardhian Dwi Putra, Diah Ajeng Setiawati

TABEL1.

Intensitas Matahari Total dan Suhu Air Laut, Destilat, Plat, dan Penguapan

\begin{tabular}{clccccc}
\hline \multirow{2}{*}{ No } & \multirow{2}{*}{ Parameter } & \multicolumn{5}{c}{ Hari } \\
\cline { 3 - 6 } & & I & II & III & IV & V \\
\hline 1 & IT $\left(\mathrm{kW} / \mathrm{m}^{2}\right)$ & 60,2 & 56,4 & 48,1 & 59,8 & 50,8 \\
2 & $\mathrm{~T}_{\text {Air Laut }}\left({ }^{\circ} \mathrm{C}\right)$ & 55,78 & 52,55 & 53,22 & 55,52 & 51,68 \\
3 & $\mathrm{~T}_{\text {Air Tawar }}\left({ }^{\circ} \mathrm{C}\right)$ & 41,63 & 42,00 & 41,88 & 39,88 & 41,50 \\
4 & T $_{\text {Lingkungan }}\left({ }^{\circ} \mathrm{C}\right)$ & 32,40 & 31,60 & 31,10 & 31,30 & 31,63 \\
5 & T $\left._{\text {Plat }}{ }^{(} \mathrm{C}\right)$ & 52,50 & 50,25 & 48,94 & 50,78 & 46,05 \\
6 & TPenguapan $^{\left({ }^{\circ} \mathrm{C}\right)}$ & 62,67 & 60,28 & 58,20 & 61,78 & 54,86 \\
\hline
\end{tabular}

Nilai suhu plat dan suhu penguapan meningkat seiring meningkatnya intensitas mahatari disebabkan plat menyerap energi sinar matahari sesuai yang diterimanya saat itu dan menggunakannya untuk menguapkan air laut yang terdapat pada alat destilator. Hal inisesuaidenganasas black yang menyatakanbahwakalor yang diserapsamadengankalorditerimaolehzatterseb utdanakansebandingdengankenaikan(perubaha n) suhuzattersebut[5].

b. Produktivitas Air Tawar

Gambar 4 menunjukan produktivitas(volume) air tawar yang dihasilkan terhadap waktu. Pada grafik tersebut terlihatbahwa terjadi peningkatan volume air tawar secara konsisten sejak pukul 10.00-12.00 WITA.Peristiwa initerjadi karena semakin siang proses destilasi dilakukan, temperatur evaporasi meningkat sehingga produktivitas (volume)air tawar yang dihasilkan dari proses evaporasi juga meningkat. Nilai produktivitas air tawar mulai menurun seiring dengan menurunnya intensitas sinar matahari (Gambar 3).Setelah pukul 14.00 posisi matahari sudah mulai bergerak ke arah barat, sehingga nilai intensitas matahari yang diterima akan semakin berkurang menjelang matahari terbenam.Faktor lain yang mempengaruhi produktivitas air bersih dari alat destilasi tenaga surya ini adalah kecepatan angin, temperatur lingkungan, dan cuaca yang dinamis.

Pada gambar 4 terlihat bahwa titik maksimum pembentukan air tawar akibat proses evaporasi terjadisekitar pukul 12.0013.00 WITA. Air kondensat yang dihasilkan pada waktu tersebut mencapai 120-140 ml, sedangkan produktivitas yang paling sedikit terdapat pada jam $08.00,16,00$ dan pukul 17.00 WITA sebesar 25-90 ml. Hal ini disebabkan oleh intensitas sinar matahari pada jam 08.00, 16.00 dan 17.00 WITA rendah dan pada jam 12.00-14.00 WITA intensitas sinar matahari tinggi. Produktivitas air yang paling banyak dihasilkan adalah pada hari kedua sebesar 695 $\mathrm{ml}$, sedangkan produktivitas yang paling sedikit adalah hari keempat sebesar $440 \mathrm{ml}$.

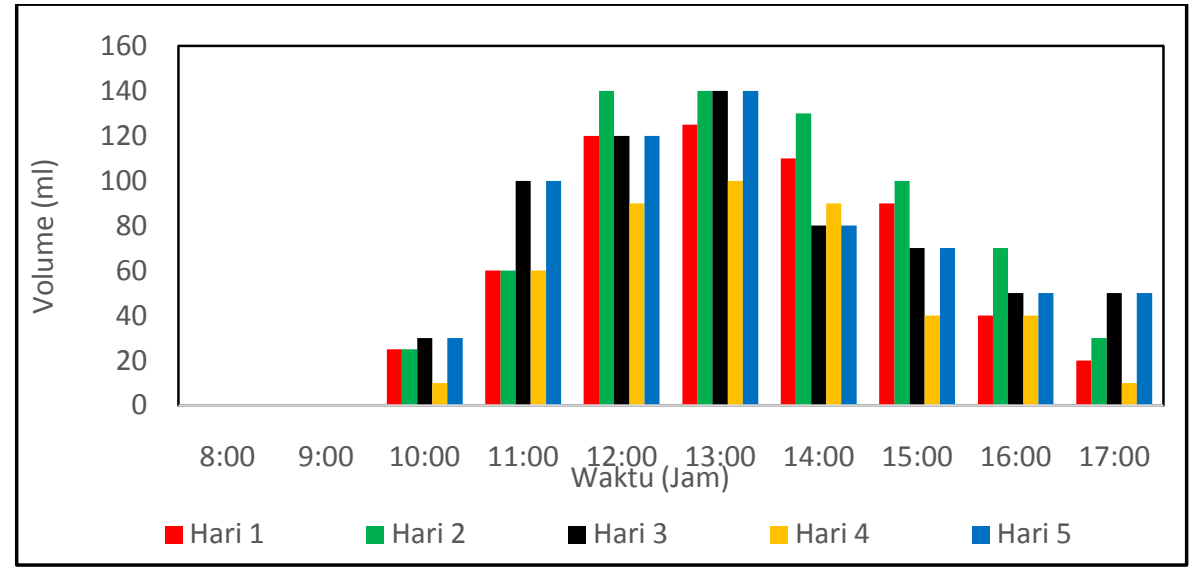

Gambar 4. Produktivitas air tawar selama 5 hari pengamatan

Tabel 2

Data Pengamatan Parameter Kualitas Air Laut dan Destilat

\begin{tabular}{clccccccc}
\hline \multirow{2}{*}{ No } & \multirow{2}{*}{ Parameter } & \multicolumn{7}{c}{ Hari Destilasi } \\
\cline { 2 - 7 } & & Air laut & I & II & III & IV & V Rata-rata \\
\hline 1 & pH & 8,10 & 7,35 & 7,19 & 7,09 & 7,03 & 7,03 & 7,14 \\
2 & Suhu ( $\left.{ }^{\circ} \mathrm{C}\right)$ & 33 & 30 & 29 & 31 & 32 & 30 & 30,4 \\
3 & TDS (ppm) & 8247 & 97 & 93 & 0,015 & 0,034 & 0,048 & 38,02 \\
\hline
\end{tabular}


Tabel 3

Kesetimbangan Energi Proses Distilasi Air laut

\begin{tabular}{cccc}
\hline Hari Ke- & Energi Masuk (J oule) & Energi Terpakai (J oule) & Efisiensi(\%) \\
\hline 1 & $2.123 .435,10$ & $1.755 .500,00$ & 82,67 \\
2 & $2.012 .144,70$ & $1.962 .350,00$ & 97,52 \\
3 & 1.965 .773 .70 & $1.766 .347,56$ & 89,85 \\
4 & $1.873 .251,75$ & $1.307 .755,28$ & 69,81 \\
5 & $1.999 .660,20$ & $1.639 .599,16$ & 81,99 \\
\hline
\end{tabular}

c. Kualitas Air Laut dan Destilat

Tabel 2 memperlihatkan kualitas air hasil destilasi. Pada sampel pengujian air laut sebelum destilasi memiliki pH 8,10 yang mengindikasikan air laut memiliki sifat basa. Berdasarkan hasil pengujian air tawar dari proses destilasi memiliki $\mathrm{pH}$ 7,03- 7,35 yang bersifat netral. Peraturan Menteri Kesehatan Republik Indonesia No. 907/MENKES/ PER/VII/ 2002 memberikan syarat standar $\mathrm{pH}$ minimum dan maksimum air minum yang di izinkan berkisar antara 6,58,5. Pada sampel pengujian air tawar $\mathrm{pH}$ terukur adalah 7,03-7,35. Nilai ini menunjukkan bahwa destilat bersifat netral dan memenuhi $\mathrm{pH}$ yang diperbolehkan oleh KEMENKES RI.

Temperatur yang didapatkan berdasarkan hasil penelitian berturut-turut tercatat sejak hari pertama pengamatan, yaitu $30^{\circ} \mathrm{C}, 29^{\circ} \mathrm{C}$, $31^{\circ} \mathrm{C}, 32^{\circ} \mathrm{C}$, dan $30^{\circ} \mathrm{C}$. Temperatur sebelum kondensasi tercatat $33^{\circ} \mathrm{C}$, lebih tinggi jika dibandingkan dengan temperatur setelah destilasi. Meskipun demikian, nilai ini masih dinyatakan layak berdasarkan KEMENKES RI.

Berdasarkan hasil penelitian, diketahui total zat terlarut (TDS) pada air tawar hasil destilasi selama 5 hari berturut-turut sebesar 97 ppm, 93 ppm, 0,015 ppm, 0,034 ppm dan 0,048 ppm. Faktor yang menentukan nilai total zat terlarut adalah kandungan garam pada air. Semakin banyak senyawa garam yang terkandung di dalam air, semakin tinggi nilai TDSnya. Setelah proses destilasi, total zat terlarut berkurang, karena zat terlarut berupa senyawa garam tidak menguap akibat titik didih senyawa garam lebih tinggi daripada air.Sehingga yang selanjutnya terkondensasi hanya uap air murni dengan total zat terlarut dibawah $100 \mathrm{ppm}$. Hal ini dengan sesuai ketetapan dari World Health Organization (WHO) yang menetapkan standar air minum sehat yang layak dikonsumsi harus memiliki kadar TDS dibawah 100 ppm.

\section{d. Kesetimbangan massa destilasi}

Untuk menghitung kesetimbangan massa destilasi digunakan hukum kesetimbangan massa, dimana massa yang memasuki sistem harus sama dengan massa yang keluar melewati sistem dan kehilangan yang terjadi akibat proses dalam sistem diasumsikan sebagai losses atau kehilangan massa. Rata-rata setelah destilasi, total destilat terbentuk sebesar $350 \mathrm{ml}$ dari total air laut yang diuji sebesar $5000 \mathrm{ml}$. Berdasarkan kesetimbangan massa, total air laut yang menguap (tidak terkondensasi) sebesar 1,645 liter dan garam yang dihasilkan sebesar 25 gram (Gambar 5) yang terhitung sebagai penyusutan air laut.

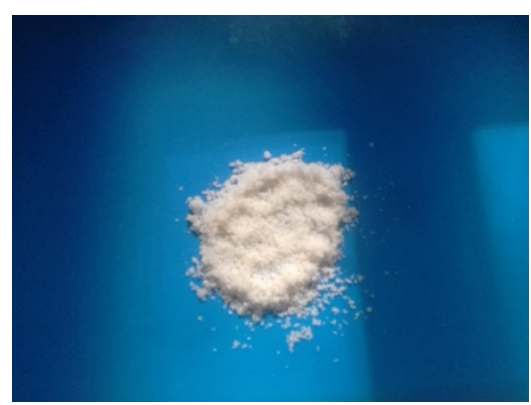

Gambar 5. Garam yang dihasilkansetelah proses destilasi

e. KesetimbanganEnergidanEfisiensi

Tabel 3 memperlihatkan nilai kesetimbangan energi pada proses destilasi dalam penelitian ini. Dari tabel terlihat bahwa selama 5 lima hari, hampir seluruh energi yang masuk digunakan untuk proses destilasi. Untuk energi yang hilang selama proses destilasi diperkirakan terjadi akibat adanya proses konduksi dan konveksi panas, baik pada dinding evaporator atau plat penyerap. Selain itu, energi yang masuk pada plat penyerap energi tidak semuanya digunakan melainkan ada sebagian kecil energi yang dipantulkan kembali, sehingga diasumsikan sebagai energi yang hilang.

Tabel 3 memperlihatkan bahwa efisiensi alat destilasi memiliki hubungan yang linier dengan jumlah energi yang masuk dalam epavorator. Adapun nilai efisiensi yang dihitung adalah nilai efisiensi perhari dari kemampuan alat destilator untuk menghasilkan air tawar. Berdasarkan pengujian dan pengamatan alat destilasi selama lima hari, didapatkan nilai efisiensi terbesar pada hari kedua dengan nilai 97,52\% sedangkan efisiensi terendah pada hari keempat dengan nilai $69,81 \%$.

Beberapa faktor yang mempengaruhi nilai efisiensi antara lain kondisi iklim dan cuaca (intensitas matahari, lama penyinaran, suhu lingkungan, hambatan angin, laju perpindahan panas dan lain sebagainya) yang berpengaruh terhadap kalor atau suhu, baikpada sistem 
destilasi maupun padalingkungan. Faktor lain yang juga dianggap berpengaruhdalam proses destilasi adalah dimensi alat destilasi serta volume air yangdidestilasi.

\section{SIMPULAN DAN SARAN}

Alat destilasi yang diamati pada penelitian ini mampu bekerja cukup baik dengan nilai produktivitas air tawar rata-rata tertinggiperharisebesar $695 \mathrm{ml}$ danterendahsebesar $440 \mathrm{ml}$.Kualitas air tawar yang dihasilkantelahsesuaistandar KEMENKES RI tahun 2014. Total kehilangan masa terjadipadasistemadalahsebesar 1,6455liter, baik yang menjadi losses danhasilendapangaram yang dihasilkan. Pada proses ini, jumlahenergimasuktertinggisebesar 2.123.435,1 Joule, energiterpakaitertinggisebesar 1.962.350 Joule, danenergi yang hilangdari plat penyerapterendahsebesar $56.844,4$ J oule.Efisiensikinerjaalattertinggididapatkansebesar 97,52\% danefisiensiterendahsebesar $\quad 69,81 \%$. Dari hasiltersebutdapatdisimpulkanbahwaperformansialatde stilasitenagasurya yang digunakansudahcukupbaik.Penelitianselanjutnyadisara nkanuntukmenggunakankaca absorber miring berbentuksegitigaatauprisma, sehinggadapat diketahuibentuk mana yang lebihefisiendalammenghasilkandestilat.

\section{E. DAFTAR PUSTAKA}

[1] Darpito H. dkk.KualitasdanPenangananPenyediaan AirBersih di Desa-desaPantai di Indonesia. Prosiding "SeminarNasionalPengelolaanSumberdaya Air di Indonesia 1996”.ITB.Bandung.1996.

[2] Astawa, K., Sucipta, M., Negara, I.P.G."AnalisaPerformansiDestilasi Air Laut Tenaga Surya MenggunakanPeyerapRadiasi Surya TipeBergelombangBerbahanDasarBeton".

3] Mulyanef, Yanthi, D.V., danMasfan, StudiEksperimentalDestilasiSuryaTripel Basin MenggunakanKolektor Plat Datar. Proseding Seminar Nasional RESATEKI, FTI Universitas Bung Hatta (2010).

[4] Sari, M.B., Yulkifli, danKamus, Z."SistemPengukuranIntensitasdanDurasiPenyinaranMata hari". J .Oto.Ktrl.Inst (J .Auto.Ctrl.Inst), Vol 7, No 1, h. 37$52,2015$.

[5] Yani, R. P., dan Said, L.,M., dan Ihsan "StudiPenentuanNilaiKaloripadaBuah Durian (Durio Zibethinus)". Teknosains, Vol 8, No 2, h. 161-174, Juli 2104. 